\title{
Factors determining career choice
}

\section{Rosanne Borg}

The answers that people provide to these questions: why do people work? why do they decide on the fields which they choose? and what factors affect their decision? are very important to career planning and subsequent satisfaction during the adult years. After all, work affects most persons between the ages of 16 and 61 , and the decisions adolescents make about their work, occupations and careers will significantly affect their future social relationships and leisure-time activities.

It is evident then that work is a major part of human experience. Many young people appear to sense that it is through work that they must ultimately validate their adult status and acquire a measure of power and self- determination. Work is so central to most of people's daily existence that their entire outlook is affected by it. In essence, a vocational decision implies a lifestyle decision. For choice of career is not an event which can be located at one point in time. It is a process which stretches back into child hood where basic personality characteristics begin to be formed (Stephens, 1970; Gothard, 1985). In making a choice, the individual will seek a career which s/he sees as desirable, as one in which s/he will have the best chance of realising the various needs, hopes and expectations which at the moment of choice s/he believes to be important.

The transition from school to work therefore is a crucial stage in the life of an adolescent. The student may have to decide whether to find a particular job, whether to follow a course or whether to go to university. In a relatively limited period, the student must, for the first time in her/his life, bring together the internal resources and those gained from adults at school and at home, in order to make a wise choice. Undoubtedly, this choice is the most important one, since it will have deep implications for her/his future.

\section{The Diversity of Influences}

Educational and vocational decisions are affected by many diverse factors, some of which are easily recognised, while others are more subtle. Factors such as the influence of the family, that of peers and of the school itself, the information available through school visits to places of work, and work experience of students, the availability of occupational information and of the demands for jobs; the difference in age, gender and personal characteristics influence the choice of a career in different ways. Several studies have shown that among the most important influences are those of the family. Arnold et al. (1988); Cherry and Gear, (1987); Mortimer and Kumka, (1982) have stressed how families are seen by most young people as extremely influential when it comes to making decisions or taking advice about their own careers. And according to West and Newton (1983) the family appears to be one of the most important categories of sources of information and help for young people, in their transition from school to work.

\section{Purpose amd Procedure}

The present study sought to examine the perceptions of a sample of Maltese fifth form students, with regard to issues relating to career choice. The study, took the form of a questionnaire survey in all Junior Lyceum State Schools in Malta and Gozo, that had fifth form students during the scholastic year 1990/1991. They were chosen on the basis of their similarity, in that all are state schools and all intakes are on the basis of an entrance examination. Moreover, all are single-sex schools and take students from $10+$ to 16. At the time the present survey was conducted, Junior Lyceum Schools had 1331 fifth formers which is roughly $61.79 \%$ of all maintained State Secondary Schools. A random sample, one in four of these students, 292 in all, represent $13.56 \%$ of all Junior Lyceum and State Area Secondary Schools.

A pilot study was carried out in a mixed youth centre with a group of 20 sixteen to seventeen year old adolescents.

This study is part of a larger study investigating factors influencing career aspirations of Maltese fifth form pupils. The collected data was used to consider possible answers to the following questions:

1. Do Maltese parents project their wishes on the sixteen year old (or so) school leaver? or do they leave it to the child's own choice? 
2. Do schools help students to make their choices?

3. Which are the life and work goals of Maltese fifth formers attending Junior Lyceums?

\section{Questionnaire}

The format of the questionnaire and the items used were developed following a review of the research literature. The interviews with school leavers devised by Moor (1976) and Grant (1987) were taken as a basis. Obviously, these interviews were adapted to the local situation with its socio-economic problems. The listed work and life goals were derived from Super in Kinnane (1971) and Hahn (1984). The occupational classification has been reproduced and adapted from Annual Abstract of Statistics (1988) covering the various types of occupations grouped in six categories.

\section{Results of Question 1}

Because of the known influence of home background on young people's ideas, attitudes and aspirations concerning career choice, it seemed worthwhile to discover how much or how little families talked about their own jobs.

Table 1 (i)

Has anyone in your family suggested any particular type of work to you?

$\begin{array}{lcccc} & \begin{array}{c}\text { girls } \\ (N=186)\end{array} & \begin{array}{c}\text { boys } \\ (N=106)\end{array} & \begin{array}{c}\text { totals } \\ (N=292)\end{array} & \begin{array}{c}\text { statistical } \\ \text { significance }\end{array} \\ \text { yes } & 145(78.0) & 76(71.7) & 221(75.7) & \text { N.S. } \\ \text { no } & 41(22.0) & 30(28.3) & 71(24.3) & \end{array}$

What type?

Table 1 (ii)

\begin{tabular}{|c|c|c|c|c|}
\hline & $\begin{array}{c}\text { girls } \\
(N=186)\end{array}$ & $\begin{array}{c}\text { boys } \\
(N=106)\end{array}$ & $\begin{array}{c}\text { lotals } \\
(N=292)\end{array}$ & $\begin{array}{l}\text { statistical } \\
\text { significance }\end{array}$ \\
\hline $\begin{array}{l}\text { A } \\
\text { Protessional } \\
\text { and managerial }\end{array}$ & $13(7.0)$ & $23(21.7)$ & $36(12.3)$ & $<0.01$ \\
\hline $\begin{array}{l}\text { B. } \\
\text { supervisory } \\
\text { and technical }\end{array}$ & $65(35.0)$ & $23(21.7)$ & $88(30.1)$ & $<0.05$ \\
\hline $\begin{array}{l}\text { C. } \\
\text { shops and } \\
\text { clerical workers }\end{array}$ & $60(32.2)$ & $19(17.9)$ & $79(27.1)$ & $=0.01$ \\
\hline $\begin{array}{l}\text { D. } \\
\text { personal service } \\
\text { (manual and non- } \\
\text { manual) }\end{array}$ & $7(3.8)$ & $5(4.7)$ & $12(4.1)$ & N/A \\
\hline $\begin{array}{l}\text { E. } \\
\text { others (skilled, } \\
\text { semi-skilled, } \\
\text { unskilled workers) }\end{array}$ & & $6(5.7)$ & $6(2.1)$ & $\mathrm{N} / \mathrm{A}$ \\
\hline $\begin{array}{l}\mathrm{F} \text {. } \\
\text { no response }\end{array}$ & $41(22.0)$ & $30(28.3)$ & $71(24.3)$ & N.S. \\
\hline
\end{tabular}

Examination of the data reveals that in nearly all the students' homes, work was certainly discussed, in fact only $3.8 \%$ of the students said that the subject was never raised. Furthermore when asked whether the family did suggest particular types of occupations to them, the findings reveal that a greater proportion of girls than boys ( $35 \%$ vs. $21.7 \%$ ) was advised by their family members to take jobs in the business world such as accountant, designer and other executive grades. Again, more girls than boys $(32.2 \%$ vs. $17.9 \%)$ are desired by the family to group themselves in the $\mathrm{C}$ category (shop and clerical). Nearly the same number of boys and girls were asked to follow the $\mathrm{D}$ category (Personal Service Occupation), while the E category which includes skilled, semi-skilled and unskilled workers was suggested to boys only. Furthermore, the data demonstrates that families expect boys more than girls to occupy higher positions in the professional and managerial occupations, in fact, the difference is statistically significant at the .01 level.

One of the several points made in Kelly's (1989) paper which considered the development of career preferences was the strong influence of perceived parental wishes on young people's plans. It is interesting to note that when asked to state what occupation they wished to take when they left school, a surprisingly high proportion of students in this study, 65 out of $88,(73.8 \%)$ in the B category have selected the same employment as suggested by their families, and 20 out of the 36 students $(55.5 \%)$ in the $A$ category expressed a similar preference. Occupational suggestions by members of the family then do affect the vocational goals of youth by influencing their aspirations similar to those held by their parents. This conclusion was also reported by Kelly (1989) and has also been observed by other researchers in this field (e.g. Moor 1976; West and Newton, 1983).

In exploring the social context of their career decision, students were shown a list of 13 possible sources $^{1}$ of help and were asked to specify who had mostly encouraged them in their decision. Examination of the data shows that parents and siblings and other relatives are people to whom students mostly turn when involved in vocational planning. The sources cited as being least influential are parents' friends and neighbours. The assistance of school friends however, is shown to be more popular amongst girls than boys. Vacancies advertised is rated equally by both sexes. Guidance teachers are shown to be a better source of information for boys, in fact, they view guidance 
teachers more as an effective source of help than do girls. For girls the necessity of self-direction seems to be more important than the advertisement of vacancies, while boys give equal importance to these two sources.

The students knowing that their parents are influential in their career plans turn to them for help with career planning more than to anyone else. This finding among Maltese students reinforce the report made by Siann et al (1990) that most young people consult with their families when making their career choices and give some thought to the impact that their career choice may have on their families.

\section{Schooling as a Factor Affecting Vocational Choice}

As indicated previously choosing a career is one of the most important decisions of anybody's life since this is a break into the adult world - a world of decision-making and choices, of options and preferences, of responsibility and self-help (Dibden and Tomlinson, 1981). No less important than family and neighbourhood in affecting vocational choice is the school (Grant and Sleeter, 1988). As early as the age of $13^{2}$, students have to make a decision by selecting the subjects they will study in the next three years leading to any school leaving certificate. Kelly (1988) reports that decisions made after this point have a direct and important influence on later occupational choices. Although not recognised as such by the pupils, perceived support from parents and teachers is found to be an important predictor of children's option choice at school. In many cases, what happens is simply that certain subjects are either excluded because the student shows no proficiency in them at the time of choice, or are rarely chosen by either sex. To some extent this process has a restricting effect on the range of occupations school leavers can hope to enter (Gothard and Goodhew, 1987). On the other hand, the fifth formers who has pursued her/his favourite school subjects may find that they are the wrong mixture for the course s/he now wishes to follow ${ }^{3}$.

\section{Results of questions 2 and 3}

\section{Subject Options}

The present study (as in Grant's [1987] and Darmanin's [1991] surveys) shows that interest in the chosen subject/s and their future occupation are considered to be the two most important reasons for both girls and boys when choosing options. In fact there was general agreement among the Maltese students that the subject option they chose at the end of form 2 , will help them in the future of their career. Significantly (.01) more girls are of the opinion that their subject choice will be of great help.

It seems that girls are more likely to have a job in mind when choosing options $(p<.05)$, while more boys seem to give greater importance to their aptitude at the subjects $(p<.05)$. This finding conforms with Darmanin's (1991) survey result which showed that more boys felt that they were good at the subject than girls ( $50 \%$ boys as opposed to $40 \%$ girls) when they were asked to give the reason for their subject option.

While $69.8 \%$ of the boys and $65.5 \%$ of the girls were determined not to change their subject option, even if they had the opportunity to do so, $32.9 \%$ of the sample felt a desire to change their subject. The percentage of students who wished to drop their subject in relation to the total number of students in that particular subject was 34.8 in sciences, 28.0 in commerce, 21.4 in arts, 42.5 in languages and other subjects.

\section{Career Guidance Provision}

Table 2

The way guidance teachers talk to students

\begin{tabular}{|c|c|c|c|c|}
\hline ways & $\begin{array}{c}\text { giris } \\
(N=186)\end{array}$ & $\begin{array}{c}\text { boys } \\
(N=106)\end{array}$ & $\begin{array}{c}\text { totais } \\
(N=292)\end{array}$ & $\begin{array}{l}\text { statistical } \\
\text { significance }\end{array}$ \\
\hline individually & $8(4.3)$ & $12(11.3)$ & $20(6.9)$ & $<.05$ \\
\hline logether in class & $98(52.7)$ & $35(330)$ & $133(45.5)$ & $<.01$ \\
\hline $\begin{array}{l}\text { individually and } \\
\text { together in class }\end{array}$ & $61(32.8)$ & $36(34.0)$ & $97(33.2)$ & N.S. \\
\hline no response & $19(10.2)$ & $23(21.7)$ & $42(14.4)$ & $<.01$ \\
\hline
\end{tabular}

When questioned about the views regarding the kind of help guidance teachers offer, quite a high percentage of students answered that they do receive help in the choice of their careers. However $14.4 \%$ of the sample said that they received no careers educa. tion whatsoever.

Perhaps the most worthy finding from this data is that $34.2 \%$ of the students reported that they talked matters over with their guidance teachers only once, while another $36.3 \%$ said that this is done every term. It should be noted (Table 2) that $52.7 \%$ of the girls and $33 \%$ of the boys reported that communication be tween them and the guidance teacher is restricted to the class with the whole group of students present and the difference between sexes is significant at 01 level. Whereas about the same proportion of girls and boys said that the guidance teacher speaks to them indi- 
vidually and collectively in the classroom, only $11.3 \%$ of the boys and $4.3 \%$ of the girls said that $\mathrm{s} / \mathrm{he}$ speaks to them individually and again the difference is significant at .05 level.

Evidence gathered suggests that more boys than girls (on their own accord) ask guidance teachers for help, and again more boys than girls view them as an effective source of help. Over $55 \%$ of the total sample, do not seek the assistance of guidance teachers. Perhaps not surprisingly, guidance is viewed by students as invaluable in careers decision. The majority of students (girls significantly more than boys at the .05 level) said that they would welcome more careers information, in fact there is also an expression of need for suggestions of new alternatives.

Table 3

The ways that schools help students with career planning

\begin{tabular}{|c|c|c|c|c|}
\hline ways & $\begin{array}{c}\text { girls } \\
(N=186)\end{array}$ & $\begin{array}{c}\text { boys } \\
(N=106)\end{array}$ & $\begin{array}{c}\text { totals } \\
(\mathrm{N}=292)\end{array}$ & $\begin{array}{c}\text { statistical } \\
\text { significance }\end{array}$ \\
\hline \multicolumn{5}{|c|}{ visits to work places } \\
\hline i. provided & $89(47.8)$ & $54(50.9)$ & $143(49.0)$ & N.S. \\
\hline ii. not provided & $97(52.2)$ & $52(49.1)$ & $149(51.0)$ & \\
\hline \multicolumn{5}{|c|}{ visits to higher sec. schools } \\
\hline i. provided & $77(41.4)$ & $40(37.7)$ & $117(40.1)$ & N.S \\
\hline ii. not provided & $109(58.6)$ & $66(62.3)$ & $175(59.9)$ & \\
\hline \multicolumn{5}{|c|}{ provision of films/videos } \\
\hline i. provided & $8(4.3)$ & $10(9.4)$ & $18(6.2)$ & N.S \\
\hline ii. not provided & $178(95.7)$ & $96(90.6)$ & $274(93.8)$ & \\
\hline \multicolumn{5}{|c|}{ provision of pamphlets } \\
\hline i. provided & $78(41.9)$ & $49(46.2)$ & $127(43.5)$ & N.S \\
\hline ii. not provided & $108(58.1)$ & $57(53.8)$ & $165(56.5)$ & \\
\hline \multicolumn{5}{|c|}{ talks by people in different industries } \\
\hline i. provided & $61(32.8)$ & $52(49.1)$ & $113(38.7)$ & $<.01$ \\
\hline ii. not provided & $125(67.2)$ & $54(50.9)$ & $179(61.3)$ & \\
\hline
\end{tabular}

As Table 3 indicates schools are providing some kind of help to the students in their career planning. But it is significant that in each way of this help, the percentage of 'not provided' is always higher to that 'provided'. Interestingly enough, it is to be noted that the help provided to boys is always higher than that to the girls except on one item, that is visits to Higher Secondary Schools.

\section{Student's Occupational Values}

What an individual values in work itself, as well as the rewards it offers, is presumably internalised in her/his vocational development and influences her/his choice of occupation. So a person's selection of a vocational field depends generally on the degree of importance s/he places upon life goals. In contrast with previous research in England (Rauta and Hunt, 1975; West and Newton, 1983) which indicates that job security was the most important factor in the choice of

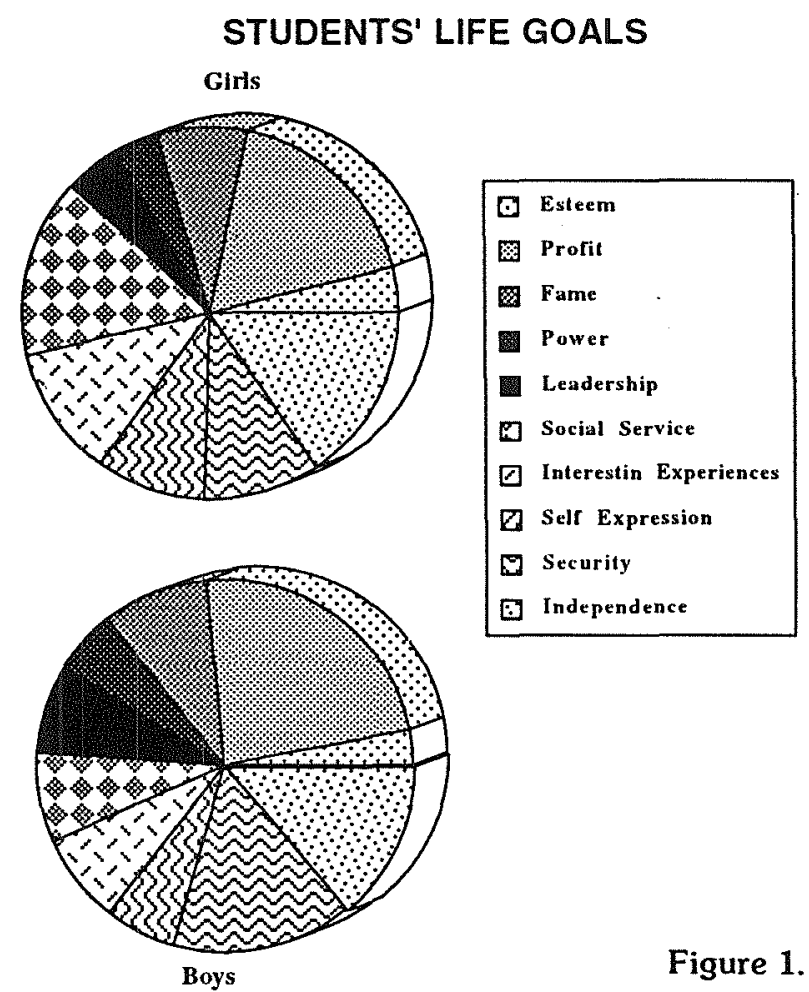

a job for all groups in their sample, in this study the money aspect is considered to be the prime motivating factor in career selection for both sexes. This is followed by opportunity for helping others and having interesting experiences for females, and job security and independence for males.

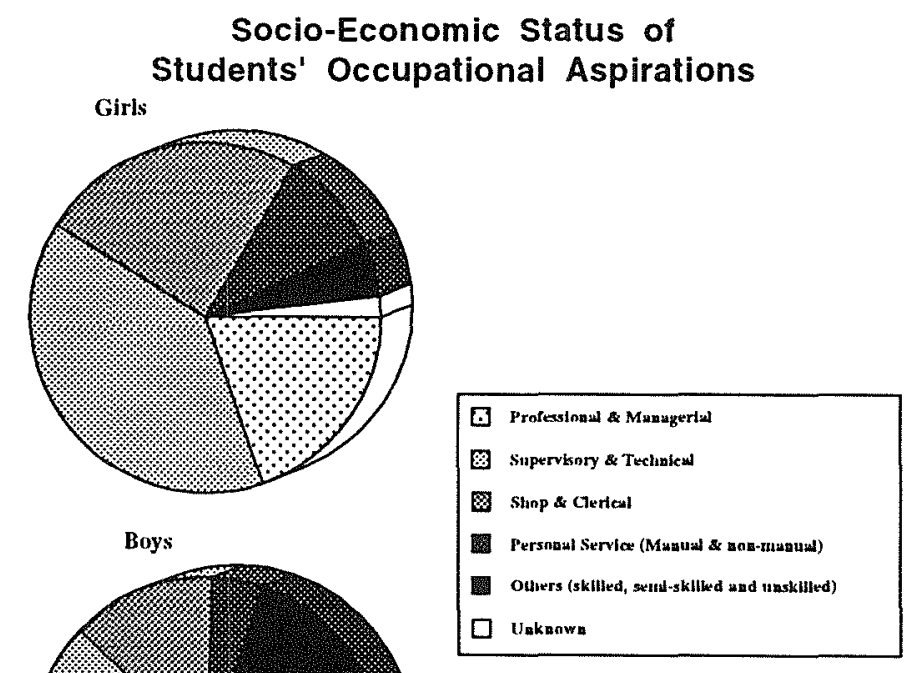


Esteem and power were viewed as being the least important by both girls and boys in the career planning process.

Girls tended to rate fame and leadership lower in importance than did boys, but only in leadership is the test significant at the .01 level. Expression of oneself appeared to be more favourable to the girls.

\section{Students' Aspirations}

Occupational values held by students in this sample, constitute an essential and important element of their motivational structure and it may provide invaluable insights into the decision-making process.

When asked to state what future occupation do they intend to follow when they left school, only 6 out of the 292 students indicated that vocational choice is still an area of indecision. The majority of students of both sexes restricted their ambitions to the supervisory and technical occupations, while a substantial number spread their jobs to the other categories. It is often pointed out that girls limit their career plans to a narrower range of occupations than boys (Furlong, 1986; Darmanin 1991). As Fig 2 shows, this pattern does not result in this study. Maltese girls are recognising today that life may hold more for them than homemaking. This may be due to two factors: girls have better opportunities to pursue a higher level of education; and a wider range of jobs is available to girls.

The findings show that young women are becoming career-oriented, in fact, the girls in this study seem to be deviating from the traditional feminine role in that they have long-term career goals which are central in their future plans. This can be partially explained by the emphasis females place on further education as an important consideration in job aspiration, and also by the way girls (though still in the minority) plan to pursue the traditional male-oriented careers of accountancy, journalism, computer programming and computer engineering. ${ }^{4}$

The reverse is not true for boys, whose future aspirations do not show any tendency towards 'female' choices. No boy out of the 14 who chose category $\mathrm{C}$ (Shop and Clerical) think of becoming secretary, neither did any boy out of the 45 in category $B$ (Supervisory and Technical) chose to be a nurse or school teacher of the primary level.

Figure 2 illustrates that many more males than females wish to enter skilled, semi-skilled and unskilled occupations $(p<.01)$. In other words, this might suggest that girls' aspirations are higher than boys'. The present results, however, still highlight the fact that boys would more likely occupy higher positions in the occupations than girls, in fact, only $18.3 \%$ as compared to $22.6 \%$ of boys, aspire to the higher administrative, professional and managerial careers. One remarkable feature in the professionat jobs is the absence of dentistry and the insistence of working in a bank by both sexes.

The percentage of students aspiring to the last two categories D and E (Personal Service Occupations and Skilled, Semi-Skilled and Unskilled) is small, but still it points that the proportion of girls aiming for personal service jobs is greater than that of boys.

\section{Students' Life Goals}

In an attempt to explore the reasons for choosing their particular future occupation, students were asked to choose one (or more) of the three given motives - enjoyment of chosen work; job security; good wages - and to give any other reason if they wished to. Results show that the main criterion for both sexes was the interest in their future work and the feeling of being good at it. Next in importance for boys came good wages, job security and other given reasons. On the other hand, girls attached more importance to job security and they ranked reasons of their own above good pay.

When describing in their own words why they wished to take up the career or occupation they chose, students generally gave reasons which were expressed in positive terms. By far, the most frequently mentioned reason given by girls was the opportunity to be useful to society. Other reasons included meeting people and haivng interesting and exciting work. As far as boys are concerned, most gave different reasons.

\section{Trial Work}

Work experience plays a most important part in the lives of many school leavers, since they gain a better appreciation beforehand of what the various types of work involve. When questioned whether they have done casual jobs $28.4 \%$ of the respondents in the survey said that they did at some stage. Girls were less likely to have had work experience than boys with $19.9 \%$ of girls and $43.4 \%$ of boys having done parttime jobs before they were interviewed. Of these students, $5.8 \%$ claim that their part-time job has some connection with their aspired future employment. 


\section{Conclusions}

In concluding it is worthwhile to mention that Malta has experienced changes in both education and availability of work. Besides, Malta had to pass through political changes along with their social consequences. The Island became Independent in 1964, was declared Republic in 1974, and has applied for membership in the European Economic Community in 1990. All these changes affected and will affect Maltese families, according to their members' age group.

The primary objective of this report was to demonstrate that among the most important influences on the educational and vocational decisions of school leavers are still those of parents. This conclusion is corroborated amongst others by Siann et al., 1990; Arnold et al; 1988; Risk, 1987 and Bratcher, 1982. Due to the impossibility to give - within this frame of presentation - a complete picture of all the findings of the project, only some major trends have been described. From the present study it has been proved that parents, and particularly the fathers regarding boys, are the main source of influence in the choice of a career among the fifth form students attending Junior Lyceums during the scholastic year $1990 / 1991$. This is confirmed by a study on the philosophy of adaptation in education in Malta. In fact, Calleja (1988, p. 31) writes that "Faced with this situation ..the family begins to assume an important role in decision."

As regards the importance of the school and the students' work and life values, the above data reveals that the future occupation was viewed by the majority of students in this sample with the criteria of profit. In the case of boys the difference of proportion test was significantly higher to that of girls $(<.05)$. Although guidance teachers gave priority to good pay in their information to all students, yet, the motive for choosing a future career was indicated by both sexes as the enjoyment of work. It seems that although there is a trend of independence among students still they are expecting more help from their schools. According to the respondents more time should be spent on careers advice and work experience. Students seem to be in dreadful need of a more adequate system of vocational counselling and vocational preparation. The following facts are also to be given due consideration. During the period of the survey, the first career exhibition was introduced by the guidance unit. ${ }^{5}$ It seems therefore, that an effort of harnessing human potential is being suggested by widening the circle of people investing in education. The whole community should be included and not just the school and the parents (Bro. Sciberras, 1988).

Preparing young people for employment, involves providing them with knowledge of the world of work in general and also more detailed information and advice about specific job opportunities. Educators therefore, can affect students by recognising their dreams, acknowledging their very real attempt to make sense of the immediate world in which they live (Grant and Sleeter, 1988). Maltese guidance teachers are today encouraging young women and men to enter the occupation they so desire and thus, are helping to eliminate the non-traditional occupational choices. By doing so, they help students to reject the stereotypical idea that males are better at certain subjects than females, and vice versa, which might discourage boys or girls from entering a certain profession.

Moreover, on account of the drive against the discrimination of sexes, more openings are being provided for females in their future occupations. Rejection of sex stereotyping indubitably enables both male and female youths to consider, as stated earlier in this study, a wide range of careers when making their vocational choices, as well as giving female adolescents more encouragement and guidance in preparing themselves for a wider array of vocations in fields from which women have histoncally been excluded.

Work experience, if co-ordinated with school work, has educational values and becomes a valuable part of the total school experience (Bent et al. 1970). In this study, it does not result that this has been the case. Such an experience, or 'trial work' where for example a two week is set aside during each term for adolescents to work in employment of their choice, definitely widens the range of their adult friendships, and provides a down to earth opportunity for learning to get along with people - peers, superiors and subordinates. Work experience visits give students a much more acurate picture of the world of work and makes the transition from school to work easier.

Furthermore, the present study indicates suggestively that among future groups of fifth formers the criteria of profit will be further strengthened. The choice of their career will be not the social status of a profession, but the productivity of their occupation and its financial aspect.

Perhaps the most important conclusion of this study is that parental influence, expressed either con- 
sciously or unconsciously, is quite strong on any youth's choice of career. In their everyday life, parents cannot avoid placing values on different occupations and the young school leaver comes under this influence. In fact in accordance with Nielsen (1987) the present study indicates that although one may think that youth's vocational decisions are more powerfully influenced by their educational experiences than by their families, yet statistics show otherwise.

Therefore, parents must see to it to provide their child with as many experiences as possible so that $\mathrm{s} /$ he can try out her/his abilities and discover where her/his potential lies. As Palmer and Cochran (1988) rightly say, they, as parents, have the advantages of greater knowledge of their children, and so they are to give personal attention to help their siblings, sort out ideas, information and values. They must realise that the period of transition between school and work is a time when adolescents need particular guidance and encouragement. For when choosing a career one is, in effect, choosing a means of implementing a selfconcept. From the personal interpretation of the data it is hoped that the result of this study will be enlightening in regard to future policies. Future policies have to consider the changes in society and its adaptations to these changes. ${ }^{6}$ Undoubtedly, the educational system is not restricted to the eductional institution. So, radical changes must come about through means other than changes in the educational system.

\section{BIBLIOGRAPHY}

Arnold. J., Budd, R.J. and Miller, K. (1988) Young People's Perceptions of the Uses and Usefulness of Different Sources of CareersHelp, British Journal of Guidance and Counselling. Vol. 16. No.1. pp. 83-90.

Bent, RK., Kronenberg, H.H. and Boardman, C.C. (1970) Principles of Secondary Education (London: McCraw-Hill).

Bratcher, W.E. (1982) The Influence of the Family on Career Selection: A farnily system perspective. Personnel and Guidance Joumal, Vol.61 No.2, pp. 87 - 91.

Calleja, J. (1988) 'Thoughts on the Concepts and Practice of the Maltese Educational System', in Fenech, V. (ed.), Education in Malta: A look to the future (Paris: UNESCO).

Central Office of Statistics (1988) Annual Abstract of Statistics (Valletta. Malta).

Cherry, N. and Gear, R. (1987) Young People's Perceptions of their Vocational Guidance Needs: Priorities and pre-occupations, British Journal of Guidance and Counselling. Vol. 15. No.l. pp. 59 - 71. Darmanin. M. (1991) 'Gender Differentials and Subject Choice in Maltese Secondary Schools' in Sultana, R. (ed.). Thernes in Education: A Maltese Reader (Malta Mireva Press).

Dibden,K. and Tomlinson,J.(eds)(1981) Information Sources in Education and Work (Cambridge: Butterworths).

Furlong, A. (1986) Schools and the Structure of Female Occupational Aspirations, British Joumal of the Sociology of Education, Vol.7, No.4, pp.367-377.

Gothard, W.P. (1985) Vocational Guidance: Theory and Practice
(Kent: Croom Helm Ltd.)

Gothard, W P. and Goodhew, E. (1987) Guidance and the Changing Curriculum (London: Croom Helm).

Grant, P.(1987) Youth Employrnent and Technological Change (Aldershot: Avebury).

Grant, C A. and Sleeter, C.E. (1988) Race, Class and Gender and Abandoned Dreams, Teachers College Record, Vol. 90, No. 1, pp. 1940. 19-40.

Hahn, M.E., Ph.D. (1984) The California Life Goals Evaluation Schedules Manual (Califomia Western Psychological Services).

Kelly, A. (1988) 'Option choice for Girls and Boys', Research in Science and Technological Education, Vol.6, No. 1, pp. 5-23.

Kelly, A. (1989) 'When I Grow Up I Want to be ...': A longitudinal study of the development of career preférences. British Joumal of Guidance and Counselling, Vol. 17. No.2, pp.179-200.

Kinnane,J.F.(1971) Vocational Motivation (Washington, D.C. Centre for Applied Research in the Apostolate).

Moor, C.H. (1976) From School to Work (London: SAGE Publications Ltd.).

Mortimer, J. and Kumka, D. (1982) A Further Examination of the Occupational Linkage Hypothesis, Sociological Quarterly. Vol. 23 Winter, pp. $3-16$

Nielsen, L. (1987) Adoloscent Psychology: A contemporary view (New York: Holt, Rinehart fand Winston, Lnc.).

Palmer, S. and Cochran, L. (1988) Parents as Agents of Career Development. Journal of Counselling Psychology. Vol. 35, No. I. pp. $71-76$.

Rauta, I and Hunt. A. (1975) Fifth Form Girls: Their hopes for the future. (London: H.M.S.O. Census Office).

Risk, J.W.F.(1987)The Recruitment Process for school-leavers: Practical and theoretical implications, British Journal of Guidance and Counselling. Vol. 15, No.3, pp. 297-312.

Sciberras, E. (Bro.) (1988) 'Harmessing Human Potential in Educational Institutions', in Fenech,V.(ed.), Education in Malta: A look to the future (Paris: UNESCO).

Siann,G., Knox, A., Thornely,E. and Evans, R.(1990) Parents, Careers and Culture: The view of ethnic-minority and ethnicmajority girls, British Journal of Guidance and Counselling, Vol. 18. No.2, pp. 156-169.

Stephens, E. W. (1970) Career Counselling and Placement in Higher Education: A student personnel function (Pennsylvania: The College Placement Council, Inc.).

West, M. and Newton. P. (1983) The Transition from School to Work'(Kent: Croom Helm Ltd.).

\section{Notes}

1. Father, mother, siblings, other relatives, guidance teachers, other teachers, school friends, other friends, father's friends, mother's friends, neighbours, vacancies advertised, self.

2. As from June 1994 students have selected subject options at the end of Form 3, at the age of 14

3. Although theoretically few doors are closed to women today for an individual can, of course, enter a career taditionally associated with the opposite sex. such as engineering for females and couriers for males, still s/he may face discrimination both in receiving training and in getting a job (Darmanin 1991).

4. Today s 16 (or so) year olds have the choice of a wide vanety of courses of higher education and of careers to which they may lead.

5. Free pamphlets intending to help parents and teachers with advice on career choice and to help students to get to know more about specific careers are being published.

6. The introduction of the family law in Malta will influence the new generations on their outlook of work. 